\title{
New and little known species of Lycostomus Motschulsky, 1861 (Coleoptera: Lycidae) from southern Asia
}

\author{
Новые и малоизвестные виды Lycostomus Motschulsky, 1861 \\ (Coleoptera: Lycidae) из Южной Азии
}

\author{
Sergey V. Kazantsev \\ С.В. Казанцев
}

Insect Centre, Donetskaya 13-326, Moscow 109651, Russia.

Инсект-центр, ул. Донецкая 13-326, Москва 109651, Россия; e-mail: kazantss@mail.ru

KEY WORDS: Coleoptera, Lycidae, new species, Oriental region.

КЛЮЧЕВЫЕ СЛОВА: Coleoptera, Lycidae, новые виды, Ориентальный регион.

ABSTRACT. Five new species of the genus Lycostomus Motschulsky, 1861, L. fifaensis, L. honestulus, $L$. kwanshanensis, L. lushanensis and L. nathani spp.n., are described from Saudi Arabia, India and China. Lycostomus atrimembris Pic, 1926, syn.n. and L. afghan Kleine, 1936, syn.n. are synonymized with, respectively, L. nigripes (Fabricius, 1787) and L. ambiguus Waterhouse, 1879. Lycus (Haplolycus) platypterus Bourgeois, 1884 is transferred to Lycostomus as $L$. platypterus (Bourgeois, 1884), comb.n. Lycostomus decorus Kleine, 1935, L. kraatzi Bourgeois, 1882, L. nigripes (Fabricius, 1787), L. poilanei Kazantsev, 1993 and L. platypterus (Bourgeois, 1884) are illustrated.

РЕЗЮМЕ. Пять новых видов жуков-краснокрылов рода Lycostomus Motschulsky, 1861, L. fifaensis, $L$. honestulus, L. kwanshanensis, L. lushanensis and L. nathani spp.n., описываются из Саудовской Аравии, Индии и Китая. Lycostomus atrimembris Pic, 1926, syn.n. и $L$. afghan Kleine, 1936, syn.n. сводятся в синонимы к, соответственно, L. nigripes (Fabricius, 1787) и L. ambiguus Waterhouse, 1879. Lycus (Haplolycus) platypterus Bourgeois, 1884 переносится в Lycostomus как L. platypterus (Bourgeois, 1884), comb.n. Приводятся иллюстрации L. decorus Kleine, 1935, L. kraatzi Bourgeois, 1882, L. nigripes (Fabricius, 1787), L. poilanei Kazantsev, 1993 и L. platypterus (Bourgeois, 1884).

\section{Introduction}

The genus Lycostomus Motschulsky, 1861 was created for one single species from Ceylon [Motschulsky, 1861] and later more than a hundred species-level taxa from the Oriental, Holarctic, Neotropical and Afrotropical regions were classified in it [Kleine, 1933]. Sometimes the taxon, and not without reason, was treated as a subgenus of Lycus Fabricius, 1787 (e.g., Kleine, 1933). In the present paper, however, pending a revision of the group, I am following the approach of most of the recent papers (e.g., Kazantsev, 1991, 1993, 2012; Bocáková, Bocák, 2007), where it is regarded as a separate genus.

The study of material from southern Asia carried out in the process of preparation of the revision has led to discovery of five new species of Lycostomus. These new species are described, some taxonomic changes are proposed and additional information on some of the already known taxa, including habitus photographs, is provided in the paper below.

The following acronyms are used in this paper: BNHM - Natural History Museum, Basel; NME Naturkundemuseum, Erfurt; ICM - Insect Center, Moscow; MUM - Museum of the University of Manchester.

\section{Material and Methods}

For examination the beetles were relaxed in water, then their detached abdomina were kept for several hours in $10 \% \mathrm{KOH}$ at room temperature. The $\mathrm{KOH}$ treated aedeagi and terminal abdominal segments were then placed in microvials with glycerin for photographing.

MSP-1 zoom stereoscopic dissecting microscope with $\mathrm{x} 8-\mathrm{x} 80$ magnification range was used. Photographs were taken with Canon EOS 6D camera and Canon MPE $65 \mathrm{~mm}$ lens.

Length of the specimens was measured from the apex of elytra to the anterior margin of vertex (rostrum was not included) or anterior margin of pronotum (in case the head was completely concealed by the pronotum). Length of rostrum was measured from the line connecting the outer margins of antennal cavities to the anterior margin of rostra (labrum was not included).

How to cite this article: Kazantsev S.V. 2018. New and little known species of Lycostomus Motschulsky, 1861 (Coleoptera: Lycidae) from southern Asia // Russian Entomol. J. Vol.27. No.4. P.371-380. doi: 10.15298/ rusentj.27.4.04 


\section{Taxonomy}

Lycinae Laporte, 1836

Lycini Laporte, 1836

Type genus: Lycus Fabricius, 1787.

\section{Lycostomus Motschulsky, 1861}

Type species: Lycostomus coccineus Motschulsky, 1861 [Lycus similis Hope 1831], by monotypy.

\section{Lycostomus similis (Hope, 1831) species group}

This species group is characterized by the short and more or less free parameres of the aedeagus (e.g., Figs 2-3, 5-6, 10-11).

Lycostomus ambiguus Waterhouse, 1879

Lycostomus ambiguus Waterhouse, 1879: 11.

Lycostomus acutecostatus Fairmaire, 1891: 1xxxix.

Lycostomus afghan Kleine, 1936: 180, syn.n.

Lycostomus orientalis Kleine, 1930: 94

MATERIAL. Afghanistan, Nurestan, Capa-Dara, $1500 \mathrm{~m}$, 29.V.1971, O. Kabakov leg. (ICM); Afghanistan, Nurestan, N Waygal, 2500 m, 10.VII.1971, O. Kabakov leg. (ICM); Afghanistan, Konar, W Barikot, 2000 m, 23.VII.1972, O. Kabakov leg. (ICM); Pakistan, Naran, Kagan V., 2670-2750 m, 3-5.VII.1979, W. Wittmer leg. (ICM and NHMB); N India, Jammu and Kashmir, Leh, $3850 \mathrm{~m}$, 10.VII.2000, Zubrik leg. (ICM); N India, Uttaranchal, Nainital distr., 5 km SE Mukteshwar, Satkhol, 1950 m, 1-10.V.2006, S. Saluk leg. (ICM); Nepal, Prov. Karnali, Distr. Humla, 6 km NW Simikot, Dandaphaya-Kermi, 2300-2800 m, 19.VI.2001, A. Kopetz leg. (ICM);

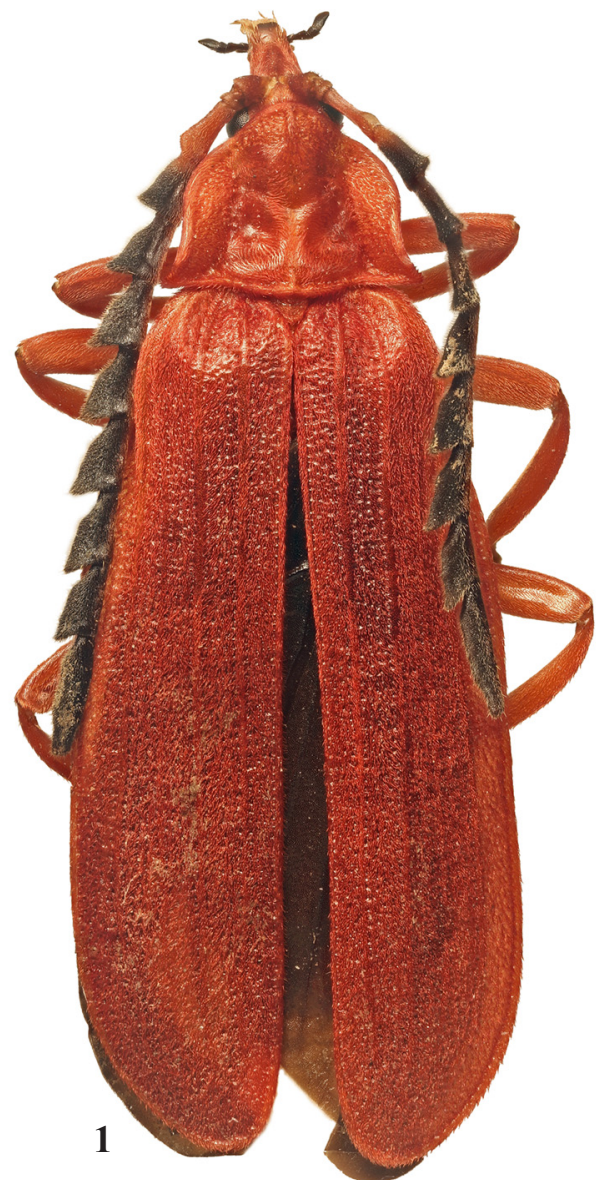

2
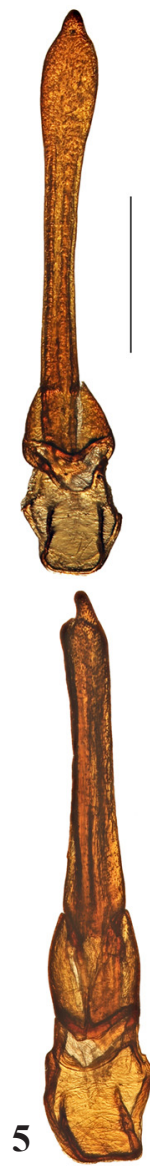

Afghanistan, Nangahar, Darah-i-Nur, Sutan vill., 1500 m, VII.2010, Reuter leg. (ICM and NME).

DISTRIBUTION. The Western Himalayas and the Hindukusch.

REMARKS. Lycostomus afghan Kleine, 1936, described from Afghanistan, is indistinguishable, both habitually and in the structure of the aedeagus, from L. ambiguus Waterhouse, 1879 , known from the adjacent areas in northern Pakistan and northeastern India (Jammu and Kashmir, Uttaranchal) [Kazantsev, 1991], as well as from western Nepal (Karnali). In this respect, Lycostomus afghan Kleine, 1936, syn.n. is placed in synonymy with L. ambiguus. First record for Nepal.

\section{Lycostomus decorus Kleine, 1935}

Figs 1-3.

Lycostomus decorus Kleine, 1935: 77.

MATERIAL. $2 \sigma^{7} \sigma^{7}$, India, Uttarkhand, Dehra Dun distr., env. Rishikesh, $330 \mathrm{~m}, 30^{\circ} 06^{\prime} 48.7^{\prime \prime} \mathrm{N}, 78^{\circ} 19^{\prime} 07.4^{\prime \prime} \mathrm{E}$, [nr.] forest stream, 12-17.IV.2012, I. Melnik leg.; $\sigma^{7}$, India, Uttarkhand, Tehri Garthwal distr., env. Nagni, 1000 m, 30 $177^{\prime} 25.1^{\prime \prime} \mathrm{N}, 78^{\circ} 21^{\prime} 30.5^{\prime} \mathrm{E}, 3-5$.V.2012, I. Melnik leg. (ICM).

DISTRIBUTION. Known only from Western Himalayas.

\section{Lycostomus kraatzi Bourgeois, 1882}

Figs 4-6.

Lycostomus kraatzi Bourgeois, 1882: 117, replacement name.

Lycostomus rufiventris (Kraatz, 1879): 125, homonym, nec L. rufiventris Waterhouse, 1879.

Figs 1-6. General view and aedeagus of Lycostomus, males: 1-3 - L. decorus; 4-6 - L. kraatzi; 1, $4-$ general view; 2-3, 5-6 aedeagus; $1-2,4-5-$ dorsally; 3,6 - laterally. Scale: $1.0 \mathrm{~mm}$.

Рис. 1-4. Общий вид и эдеагус Lycostomus, самцы: 1-3 - L. decorus; 4-6 - L. kraatzi; 1, 4 - общий вид; 2-3, 5-6 - эдеагус; 1-2, 4-5 - сверху; 3, 6 - сбоку. Масштабная линейка: 1,0 мм. 
MATERIAL. 'Syria' (ICM and ZIN); 'Lycostomus sp., Kulu' (ICM and ZIN); 'Syrie: Akbês, Etê 1880, Ch.Delagrange' (ICM); Türkei, Prov. Seyhan, Uskiyen Gecidi, $800-950 \mathrm{~m}, 37^{\circ} 41^{\prime} \mathrm{N}, 35^{\circ} 48^{\prime}$ E, 7.VI.1983, Aspöck, Rausch \& Ressl leg. (BNHM and ICM); Turcia mer., Bey Dagh, Kymluca Yenbey, 800 m, 20.V.1993, A.Weigel leg. (ICM and NME); Turchia, Prov. Antalya, Akseki, 1000 m, 4.VII.1993, G.Sama leg. (ICM); S Turkey, Antalya, 300-600 m, 24-30.V.1996, V.Siniaev (ICM); S Turkey, Isparta, Kovada Nat. Park, 1000-1500 m, 17-18.VI.2000, S. \& I.Kazantsev (ICM); Tuerkei, Antalya, Bay Daglari, 1200 m, 31.V.2002, W. \& Y.Stumpf leg. (ICM); Turcia m., Prov. Antalya, $10 \mathrm{~km}$ N Demirtas, Sedre-Tal, $500 \mathrm{~m}, 36^{\circ} 30^{\prime} 22^{\prime \prime} \mathrm{N}, 32^{\circ} 15^{\prime} 44^{\prime \prime}$ E, 25.V.2006, A.Skale leg. (ICM and NME); Turcia m., Prov. Antalya, $15 \mathrm{~km}$ NE Alanya, Dim Say River, 130 m, 36 $36^{\circ} 33^{\prime} 39^{\prime} \mathrm{N}, 32^{\circ} 12^{\prime} 48^{\prime \prime}$ E, 30.V.2006, A.Weigel leg. (ICM and NME); Turkey, Mersin Prov., nr. Camilyayla, Sebil, 30.VI.2010, D.Kasatkin leg. (ICM).

DISTRIBUTION. Known from southern Turkey and northern Syria.

Lycostomus poilanei Kazantsev, 1993

Figs 7-11.

Lycostomus poilanei Kazantsev, 1993: 59.

MATERIAL. Guangdong (ICM).

DISTRIBUTION. Northern Vietnam (Shapa) and south- eastern China (Guangdong). First record for China.

REMARKS. Lycostomus poilanei seems to be standing out among the other members of the genus due to the widened proximally spiculum gastrale (Fig. 9) and distinctly separated parameres of the aedeagus (Figs 10-11).

Lycostomus platypterus (Bourgeois, 1884), comb.n. Figs 12-14.

Lycus (Haplolycus) platypterus Bourgeois, 1884: 65.

MATERIAL. Saudi Arabia, Fifa, nr. Gizan, 27-31.III.1983, C. Holzschuh leg. (ICM).

DISTRIBUTION. Arabian Peninsula.

REMARKS. As already Kleine [1937] mentioned, there seems to be no difference between Lycus subg. Haplolycus Bourgeois, 1883 and Lycostomus. While the true status of the taxa should be clarified by the examination of their type species within the revision of the whole group, it seems appropriate to note that L. (H.) platypterus Bourgeois, 1884 described from the Arabian Peninsula undoubtedly belongs in Lycostomus and is, therefore, transferred to the said genus as Lycostomus platypterus (Bourgeois, 1884), comb.n.
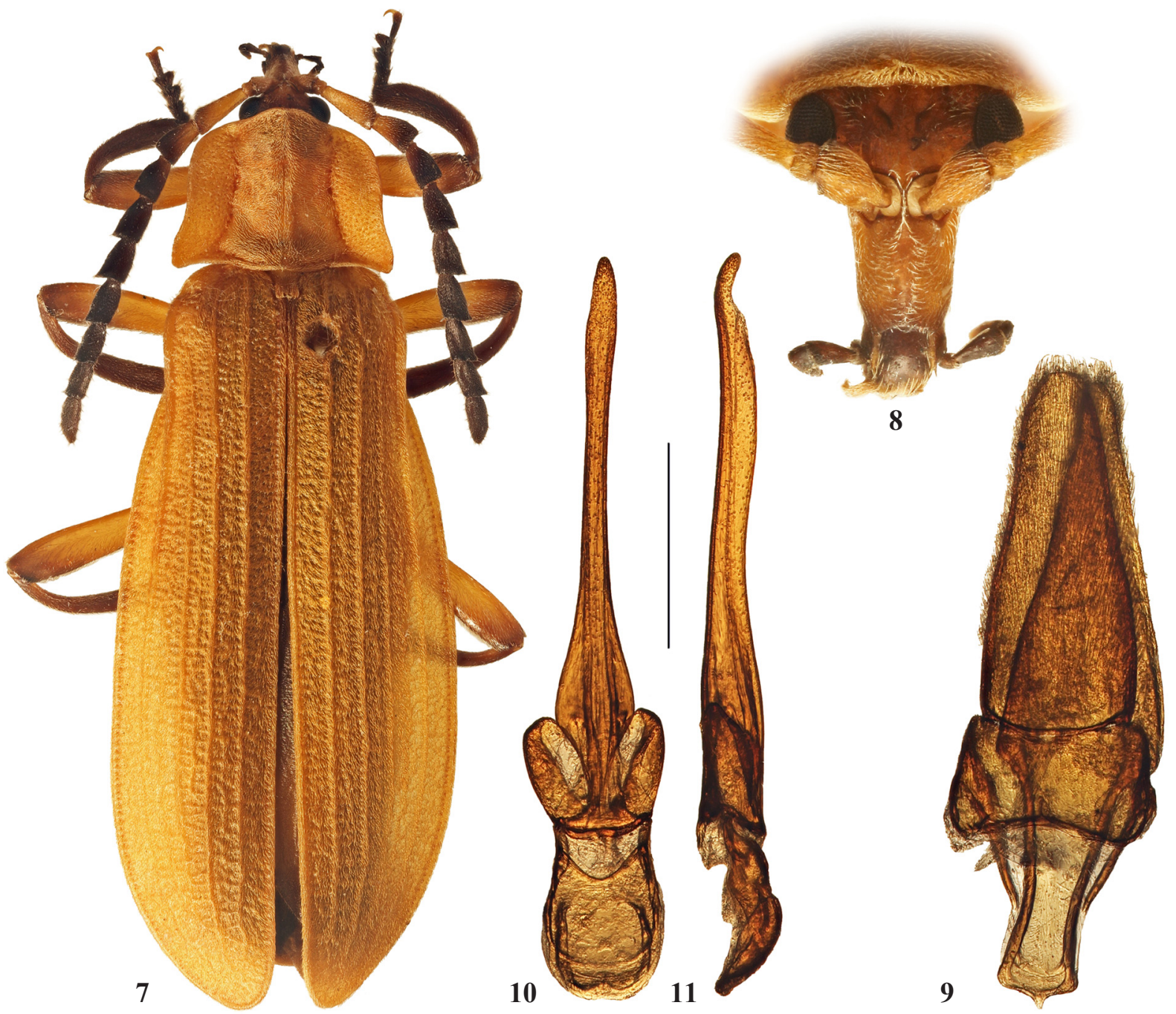

Figs 7-11. General view and details of Lycostomus poilanei, male: 7 - general view; 8 - rostrum; 9 - ultimate abdominal segments; 10-11 - aedeagus; 7-10 - dorsally; 11 - laterally. Scale: $1.0 \mathrm{~mm}$.

Рис. 7-11. Общий вид и детали строения Lycostomus poilanei, самец: 7 - общий вид; 8 - рострум; 9 - вершинные брюшные сегменты; 10-11 - эдеагус; 7-10 - сверху; 11 - сбоку. Масштабная линейка: 1,0 мм. 


\section{Lycostomus fifaensis Kazantsev, sp.n. \\ Figs 15-18.}

MATERIAL. Holotype, $0^{7}$, Saudi Arabia, Fifa, nr. Gizan, 27 31.III.1983, C. Holzschuh leg. (ICM).

Description. Male. Dark brown to black; scape proximally and pedicel (antennomere 2) light brown; pronotum and elytra, except at distal third, testaceous (Figs 15-16).

Vertex punctate, hairy, with conspicuous impression behind antennal prominence. Eyes small, interocular distance ca. 1.8 times greater than eye diameter. Rostrum parallel-sided, moderately long, ca. 1.2 times longer than wide proximally, anteriorly convex. Labrum transverse, almost straight anteriorly, rounded at sides. Palps slender, ultimate palpomeres elongate, narrowed and glabrous distally. Antennal sockets separated by minute
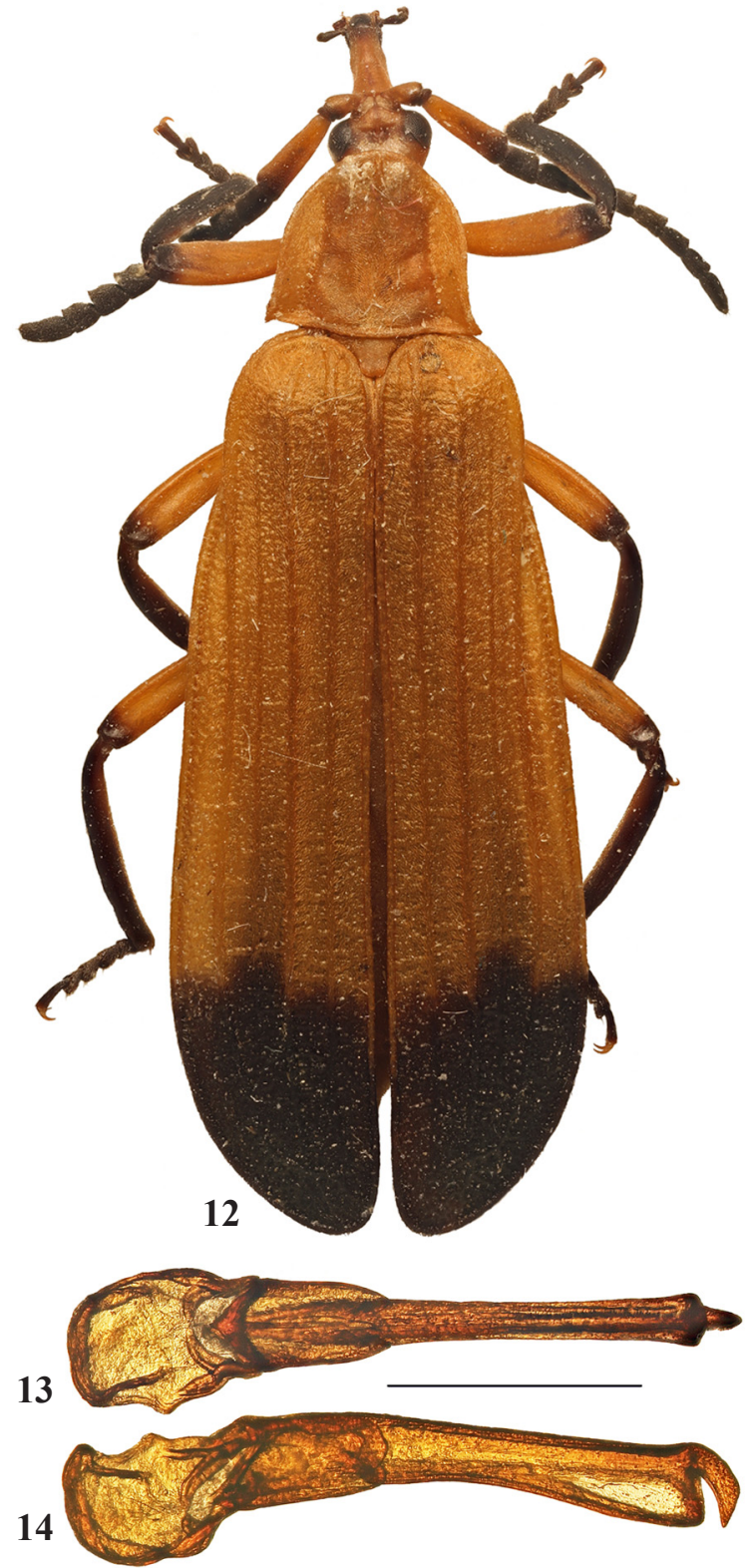

Figs 12-14. General view and aedeagus of Lycostomus platypterus, male: 12 - general view; $13-14$ - aedeagus; $12-13$ - dorsally; 14 - laterally. Scale: $1.0 \mathrm{~mm}$.

Рис. 12-14. Общий вид и эдеагус Lycostomus platypterus, самец: 12 - общий вид; 13-14 - эдеагус; $12-13$ - сверху; 14 сбоку. Масштабная линейка: 1,0 мм. lamina (Fig. 16). Antennae dentate, attaining to elytral third; antennomere 3 ca. 7 times longer than antennomere 2 and ca. 1.2 times longer than antennomere 4; antennomeres 3-11 with short scarce decumbent pubescence (Figs 15-16).

Pronotum transverse, ca. 1.5 times wider than long, almost straight basally and semi-circular anteriorly, with prominent acute posterior and rounded anterior angles; median rib noticeable only anteriorly, with median groove almost entirely flat in the middle. Scutellum triangular, rounded at apex (Fig. 15).

Elytra ca. 3 times longer than wide at humeri, noticeably widened posteriorly, widest in distal fourth, with four prominent, equally developed primary costae, except less conspicuous costa 3 ; interstices with irregular reticulation. Pubescence extremely short, hardly noticeable. Femoris and tibiae narrow, straight; tarsi relatively narrow, tarsomeres 1 and 2 with plantar pad in apical half (Fig. 15).

Spiculum gastrale proximally rounded, not widened. Aedeagus symmetric, with straight elongate median lobe, slightly widened in distal half and narrowed near apex; parameres closely attached to median lobe, ca. 0.2 length of median lobe; phallobase elongate, ca. 1.4 times longer than wide and about 0.3 length of median lobe, with semicircular distal opening, short lateral apodemes and a pair of evident sutures proximally (Figs 17-18).

Female. Unknown.

Length: $9.4 \mathrm{~mm}$. Width (humerally): $2.3 \mathrm{~mm}$.

DIAGNOSIS. Lycostomus fifaensis sp.n. is readily distinguishable from $L$. platypterus, the only other Lycostomus species known from the Arabian Peninsula, by the uniformly dark brown to black underside, shorter rostrum, broader pronotum, more prominent elytral costae and reticulation, as well as by the differently structured apex of the median lobe of the aedeagus (Figs 15-18).

ETYMOLOGY. The new species is named after the type locality.

\section{Lycostomus nigripes (Fabricius, 1787) species group}

The Lycostomus nigripes (Fabricius, 1787) species group is characterized by the long parameres, completely fused to the median lobe (e.g., Figs 21-22).

\section{Lycostomus nigripes (Fabricius, 1787)}

Figs 19-22.

Pyrochroa nigripes Fabricius, 1787: 163

Lycostomus atrimembris Pic, 1926: 31, syn.n.

Lycostomus jeanvoinei Pic, 1927: 4.

MATERIAL. + , S Vietnam, prov. Gialai-Contum, Buon Loi, tropical forest, 5.VII.1985, L. Medvedev leg. (ICM); $\bigcirc^{7}$, China, S Yunnan, Xishuanbanna 23 NW Jinghong, Na Bang village, $22^{\circ} 10.4^{\prime}$ N, 100 39.5' E, 680 m, 5.V.2008, A. Weigel leg. (ICM).

DISTRIBUTION. Southeastern Palaearctic and northern Oriental regions.

REMARKS. It was already noted that the aedeagus of $L$. atrimembris Pic, 1926 closely resembles that of L. nigripes [Kazantsev, 1993], the latter species, on the other hand, reported to be fairly variable (e.g., Kazantsev, 1991). Lycostomus atrimembris appeared to be possibly different from typical $L$. nigripes in having uniformly testaceous elytra, more deflexed sides of the pronotum and slightly wider distally elytra, all these character states, however, falling within the intraspecific variability range. The lectotype of $L$. atrimembris is a female from northern Vietnam ('Chapa') [Kazantsev, 1993]. Now, with a male specimen, agreeing with the lectotype in all external characters and also possessing the aedeagus of $L$. nigripes, available from a nearby locality (Xishuanbanna in 
South Yunnan), it seems possible to assert that the two taxa are identical. Hence, Lycostomus atrimembris Pic, 1926, syn.n. is a junior synonym of $L$. nigripes (Fabricius, 1787).

\section{Lycostomus honestulus Kazantsev, sp.n.}

Figs 23-26.

MATERIAL. Holotype, $O^{7}$, India, [Himachal Pradesh, Chamba distr.], Dalhousie (ICM); paratype, + , same label (ICM).

DESCRIPTION. Male. Dark brown to black; broad pronotal sides and elytra reddish brown (Fig. 23).

Vertex shining, with scarce pubescence, bearing a pair of conspicuous round impressions behind antennal prominence. Eyes relatively small, interocular distance ca. 1.7 times greater than eye diameter. Rostrum slightly narrowing anteriorly, moderately long, ca. 1.2 times longer than wide proximally, anteriorly noticeably concave. Labrum elongate, convex anteriorly, slightly rounded at sides. Palps slender, ultimate palpomeres elongate, parallel-sided, oblique distally. Antennal sockets separated by minute lamina (Fig. 24). Antennae dentate, attaining to elytral middle; antennomere 3 ca. 4.5 times longer than antennomere 2 and ca. 1.1 times longer than antennomere 4; antennomeres 3-11 with short scarce decumbent pubescence (Fig. 23).

Pronotum transverse, ca. 1.5 times wider than long, densely punctate, slightly bisinuate basally and triangularly pro- duced anteriorly, with prominent acute and truncate posterior and broadly rounded anterior angles; median rib noticeable only anteriorly, with inconspicuous narrow median groove in the middle. Scutellum triangular, almost truncate at apex (Fig. 23).

Elytra ca. 3.5 times longer than wide at humeri, conspicuously widened posteriorly, widest in distal third, with four narrow, equally developed primary costae, except less conspicuous near humerus costa 3 ; interstices with irregular reticulation. Pubescence short, decumbent, densely covering reticulation. Femoris and tibiae narrow, straight; tarsi relatively narrow, tarsomeres 1 and 2 with plantar pad in apical two thirds (Fig. 23).

Spiculum gastrale proximally rounded, not widened. Aedeagus symmetric, with narrow elongate median lobe, broadly oval in distal half, mildly bent in lateral aspect and constricted near apex; parameres closely attached to median lobe, ca. 0.5 length of median lobe; phallobase elongate, ca. 1.5 times longer than wide and about 0.3 length of median lobe, with oval distal opening, short lateral apodemes and a pair of evident sutures proximally (Figs 25-26).

Female. Similar to male, but eyes somewhat smaller and antennae slightly shorter and less dentate.

Length: 14.6-15.4 mm. Width (humerally): $3.5-3.8 \mathrm{~mm}$.

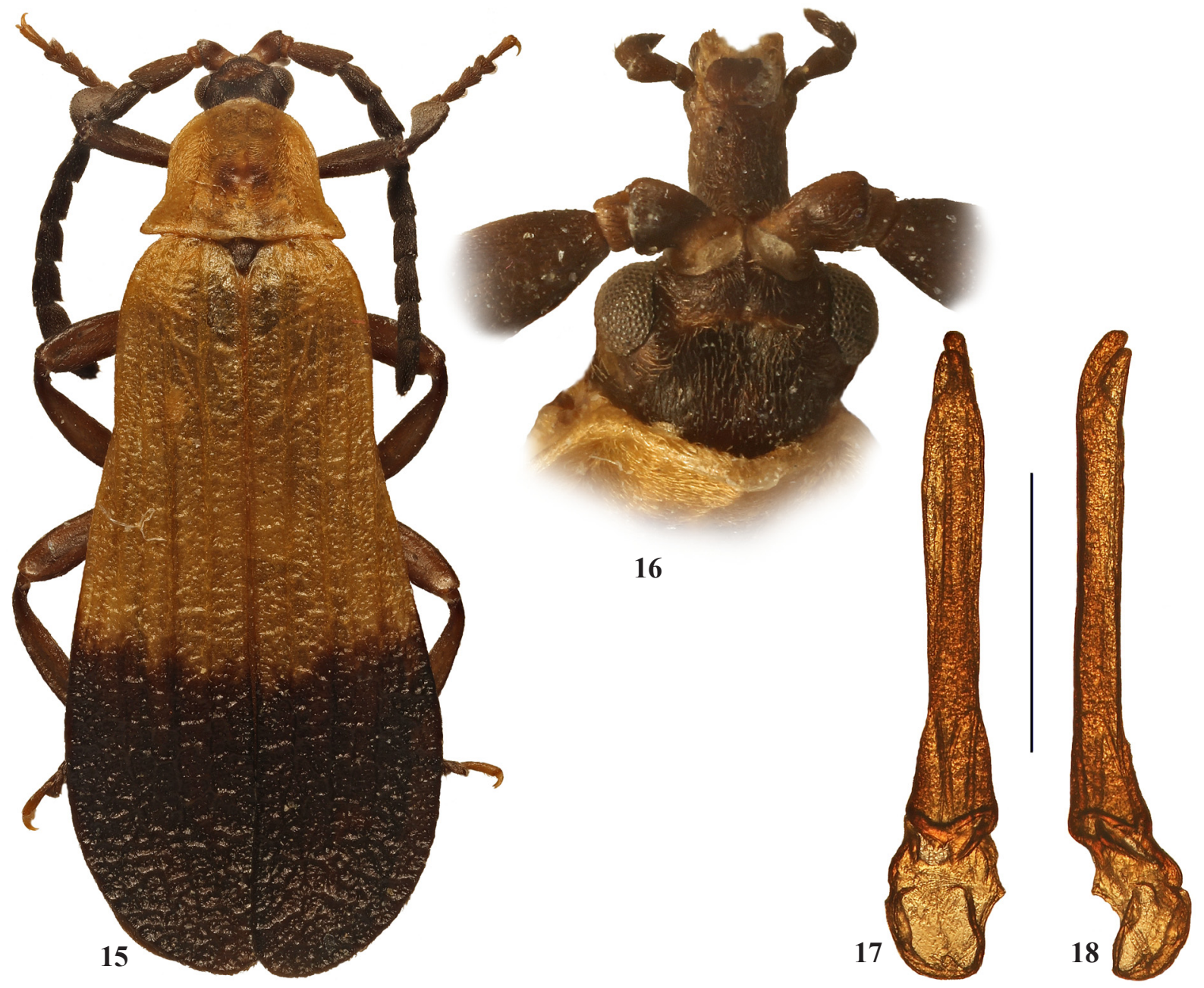

Figs 15-18. General view and details of Lycostomus fifaensis sp.n., male, holotype: 15 - general view; 16 - rostrum; 17-18 aedeagus; $15-17$ - dorsally; 18 - laterally. Scale: $1.0 \mathrm{~mm}$.

Рис. 15-18. Общий вид и детали строения Lycostomus fifaensis sp.n., самец, голотип: 15 - общий вид; 16 — рострум; 17-18 эдеагус; 15-17- сверху; 18 - сбоку. Масштабная линейка: 1,0 мм. 
ETYMOLOGY. The new species is named after Lycostomus honestus Bourgeois, 1885, alluding to the similarity between the two species.

DIAGNOSIS. Lycostomus honestulus sp.n. resembles, both in general appearance and in the structure of the aedeagus, L. honestus, also from the Himalayas [Kazantsev, 1991], distinguishable by the bent in lateral aspect median lobe of the aedeagus, with broadly oval, in dorsal aspect, proximal half (Figs 25-26).

\section{Lycostomus kwanshanensis Kazantsev, sp.n. Figs 27-31.}

MATERIAL. Holotype, $0^{7}$, TAIWAN: Taoyuan, Da Kwan Shan, Giant forest, 1100 m, 9.IX.1984, W.-J. Wu leg. (ICM); paratypes, $\sigma^{7}$, same label; $\sigma^{7}$, TAIWAN: Ilan, Taipingshan, 25-28.VII.1983, W.-J. Wu leg. (ICM)

DESCRIPTION. Male. Dark brown to black; broad pronotal sides and elytra reddish brown (Fig. 27).

Vertex shining, finely punctate, with scarce pubescence, bearing a pair of conspicuous round impressions behind antennal prominence. Eyes small, interocular distance ca. 2.3 times greater than eye diameter. Rostrum narrowing anteriorly, relatively short, about as long as wide proximally, anteriorly truncate. Labrum slightly elongate, convex anteriorly, almost straight at sides. Palps slender, ultimate palpomeres elongate, narrowed and glabrous distally. Antennal sockets separated by narrow lamina (Fig. 28). Antennae dentate, attaining to elytral two fifths; antennomere 3 ca. 9 times longer than antennomere 2 and ca. 1.1 times longer than antennomere 4; antennomeres 3-11 with short scarce decumbent pubescence (Fig. 27).
Pronotum transverse, ca. 1.5 times wider than long, coarsely punctate at sides, slightly bisinuate basally and triangularly produced anteriorly, with prominent acute posterior and broadly rounded anterior angles; median rib noticeable only anteriorly, with conspicuous diamond-shaped median groove in the middle. Scutellum subquadrate, rounded at apex (Fig. 27).

Elytra ca. 3.3 times longer than wide at humeri, noticeably widened posteriorly, widest in distal fourth, with four equally developed primary costae, except more conspicuous in proximal half costae 1 and 4 and less conspicuous near humerus costa 3 ; interstices with rough irregular reticulation and traces of secondary costae. Pubescence short, decumbent, densely covering reticulation. Femoris and tibiae narrow, femoris straight, tibiae noticeably curved; tarsomeres 1 and 2 relatively narrow, with plantar pad in apical half, tarsomeres 3 and 4 moderately widened (Fig. 27).

Spiculum gastrale relatively marrow, proximally not widened (Fig. 29). Aedeagus symmetric, with narrow elongate median lobe, bent and noticeably constricted near apex in lateral aspect; parameres closely attached to median lobe, elongate, ca. 0.5 length of median lobe; phallobase elongate, ca. 1.2 times longer than wide and about 0.3 length of median lobe, with oval distal opening, short lateral apodemes and a pair of evident sutures proximally (Figs 30-31).

Female. Unknown.

Length: $10.0 \mathrm{~mm}$. Width (humerally): $2.7 \mathrm{~mm}$.

ETYMOLOGY. Species is named after the type locality.

DIAGNOSIS. Lycostomus kwanshanensis sp.n., resembling $L$. nigripes in general appearance, has the aedeagus similar in shape to that of L. poilanei (Figs 10-11), but is easily separable, from the former — by the broad black median
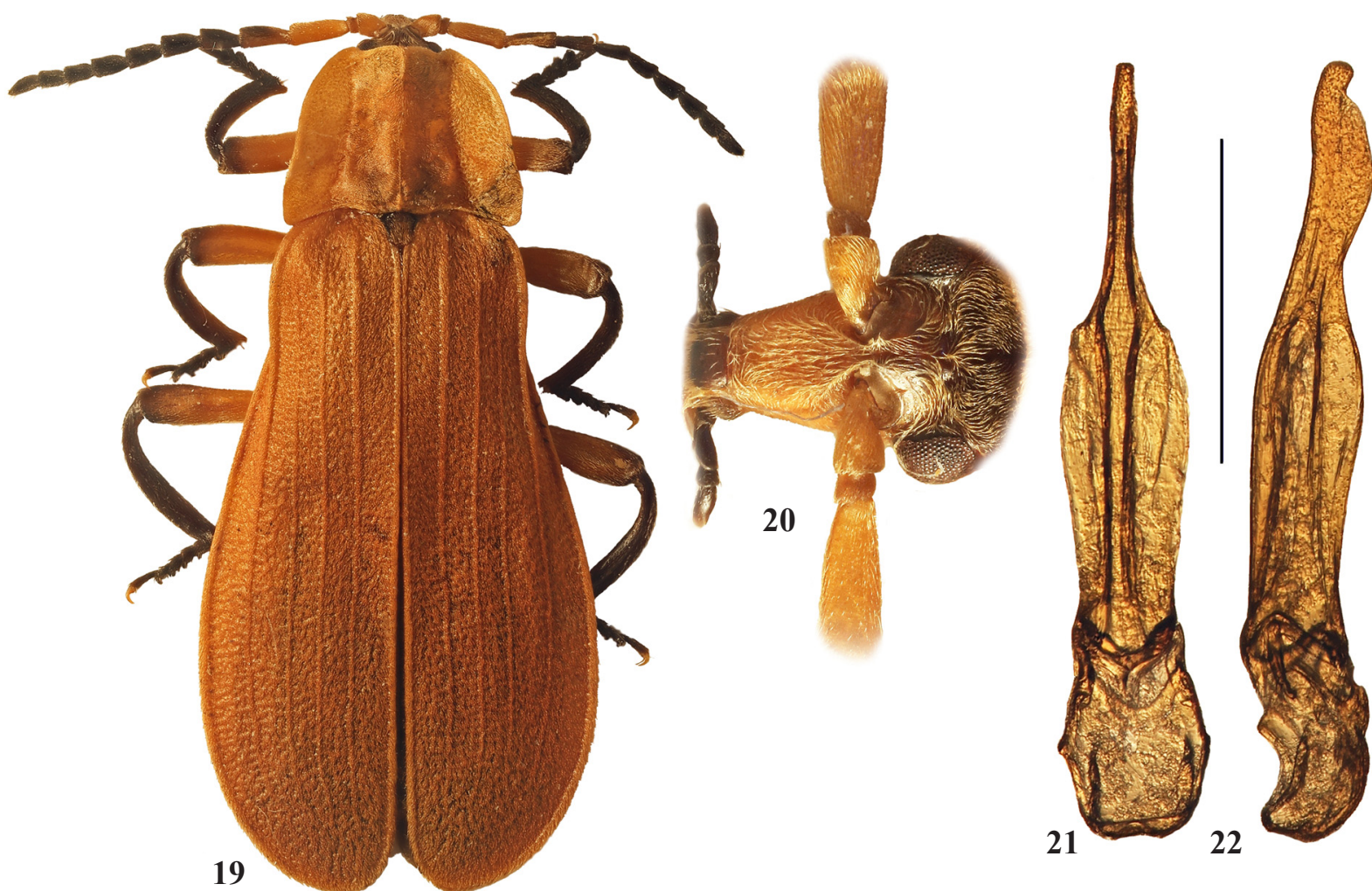

Figs 19-22. General view and details of Lycostomus nigripes, male: 19 - general view; 20 - rostrum; $21-22$ — aedeagus; 19-21 dorsally; 22 - laterally. Scale: $1.0 \mathrm{~mm}$.

Рис. 19-22. Общий вид и детали строения Lycostomus nigripes, самец: 19 - общий вид; 20 - рострум; 21-22 — эдеагус; $19-$ 21 - сверху; 22 - сбоку. Масштабная линейка: 1,0 мм. 
pronotal stripe (Fig. 27), from the latter - by the not widened proximally spiculum gastrale (Fig. 29) and elongate parameres fused to the median lobe of the aedeagus (Figs 30-31).

VARIATION. While in the holotype the abdomen is entirely dark brown to black, in the two paratypes it is testaceous laterally.

\section{Lycostomus lushanensis Kazantsev, sp.n.}

Figs 32-35.

MATERIAL. Holotype, $0^{7}$, China: S Sichuan, S Xichan, Lushan Mt., 1600-1800 m, 25-28.VII.1996, S. Kazantsev leg. (ICM).

DESCRIPTION. Male. Dark brown to black; rostrum, antennomeres $1-5$, femoris proximally and abdomen laterally testaceous; broad pronotal sides, narrow anterior and posterior pronotal margins and elytra, except at suture in scutellar area, red (Fig. 32).

Vertex flat, with shallow transverse impression behind antennal prominence. Eyes small, interocular distance ca. 1.9 times greater than eye diameter. Rostrum narrowing anteriorly, slightly longer than wide proximally, anteriorly almost truncate Labrum subquadrate, convex anteriorly, almost straight at sides.
Palps slender, ultimate palpomeres elongate, oval, rounded and glabrous distally. Antennal sockets separated by relatively broad lamina (Fig. 33). Antennae dentate, attaining to elytral middle; antennomere $3 \mathrm{ca}$. 5.4 times longer than antennomere 2 and ca. 1.5 times longer than antennomere 4; antennomeres 3-11 with short scarce decumbent pubescence (Fig. 32).

Pronotum transverse, ca. 1.6 times wider than long, coarsely punctate at sides, bisinuate basally and triangularly produced anteriorly in the middle, with prominent acute posterior and blunt anterior angles; median rib noticeable only anteriorly, with narrow median groove behind the middle. Scutellum subquadrate, concave, almost truncate at apex (Fig. 32).

Elytra ca. 2.7 times longer than wide at humeri, conspicuously widened posteriorly, widest in distal third, with four narrow, equally developed primary costae, except more conspicuous in proximal half costae 1 and 4 and less conspicuous near humerus costa 3 ; interstices with weak irregular reticulation. Pubescence short, decumbent, densely covering reticulation. Femoris and tibiae relatively narrow, femoris straight, tibiae noticeably curved; tarsi relatively

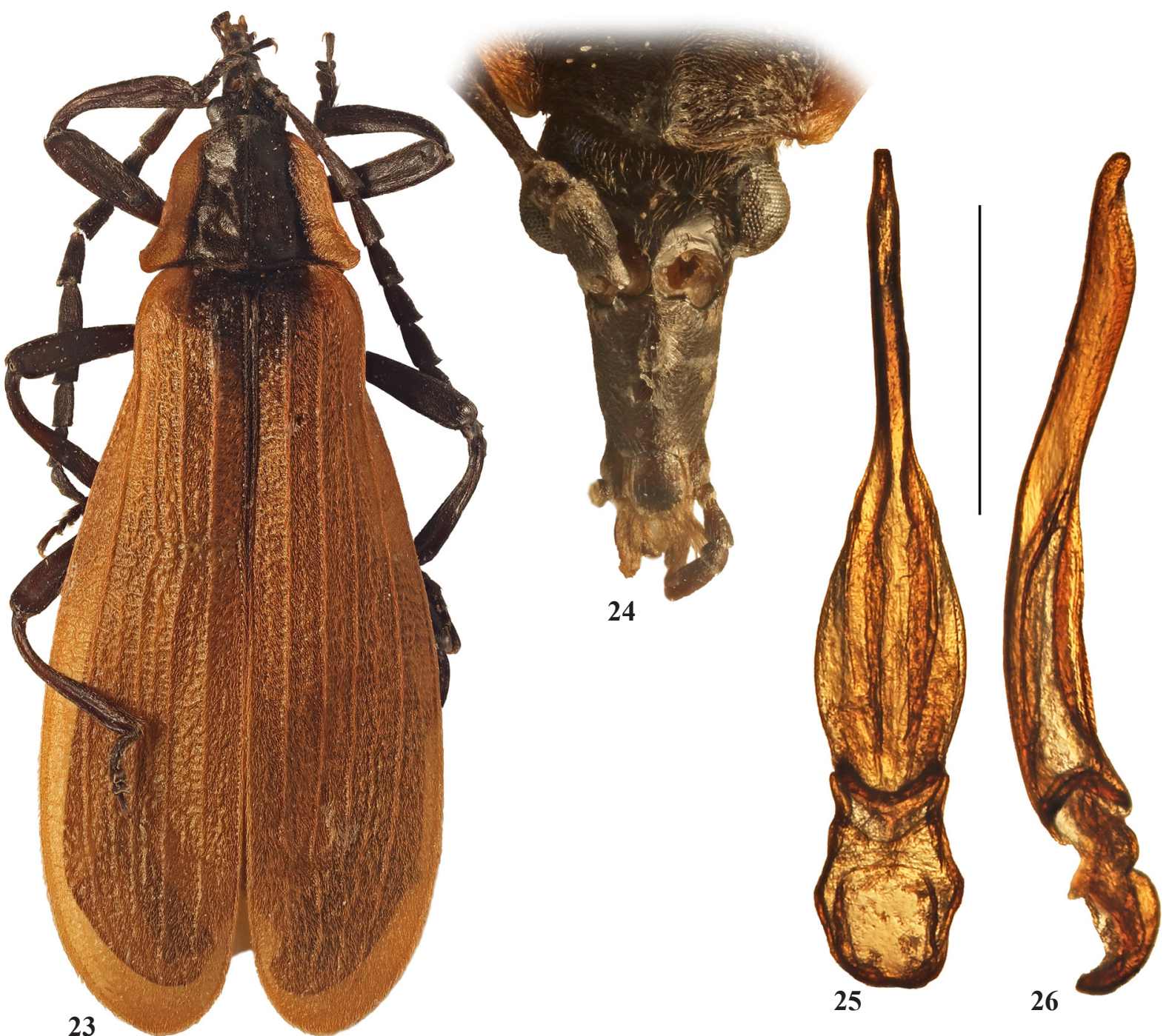

Figs 23-26. General view and details of Lycostomus honestulus sp.n., male, holotype: 23 - general view; 24 - rostrum; $25-26$ aedeagus; $23-25$ - dorsally; 26 - laterally. Scale: $1.0 \mathrm{~mm}$.

Рис. 23-26. Общий вид и детали строения Lycostomus honestulus sp.n., самец, голотип: 23 - общий вид; 24 - рострум; 2526 - эдеагус; 23-25 - сверху; 26 - сбоку. Масштабная линейка: 1,0 мм. 
wide, tarsomeres 1 and 2 with plantar pad in almost entire their length (Fig. 32).

Spiculum gastrale narrow, parallel-sided, proximally rounded, not widened. Aedeagus symmetric, with narrow (broad in lateral aspect) elongate median lobe, slightly bent and constricted near apex in lateral aspect; parameres broad, closely attached to median lobe, ca. 0.5 length of median lobe; phallobase elongate, ca. 1.5 times longer than wide and about 0.4 length of median lobe, with oval distal opening, short lateral apodemes and a pair of evident sutures proximally (Figs 34-45).

Female. Unknown.

Length: $14.3 \mathrm{~mm}$. Width (humerally): $4.1 \mathrm{~mm}$.

ETYMOLOGY. The new species is named after the type locality.

DIAGNOSIS. Lycostomus lushanensis sp.n. is apparently related to $L$. nigripes, distinguishable by the noticeably longer rostrum and labrum (Fig. 33), as well as by the broader basally median lobe of the aedeagus (Figs 34-35).

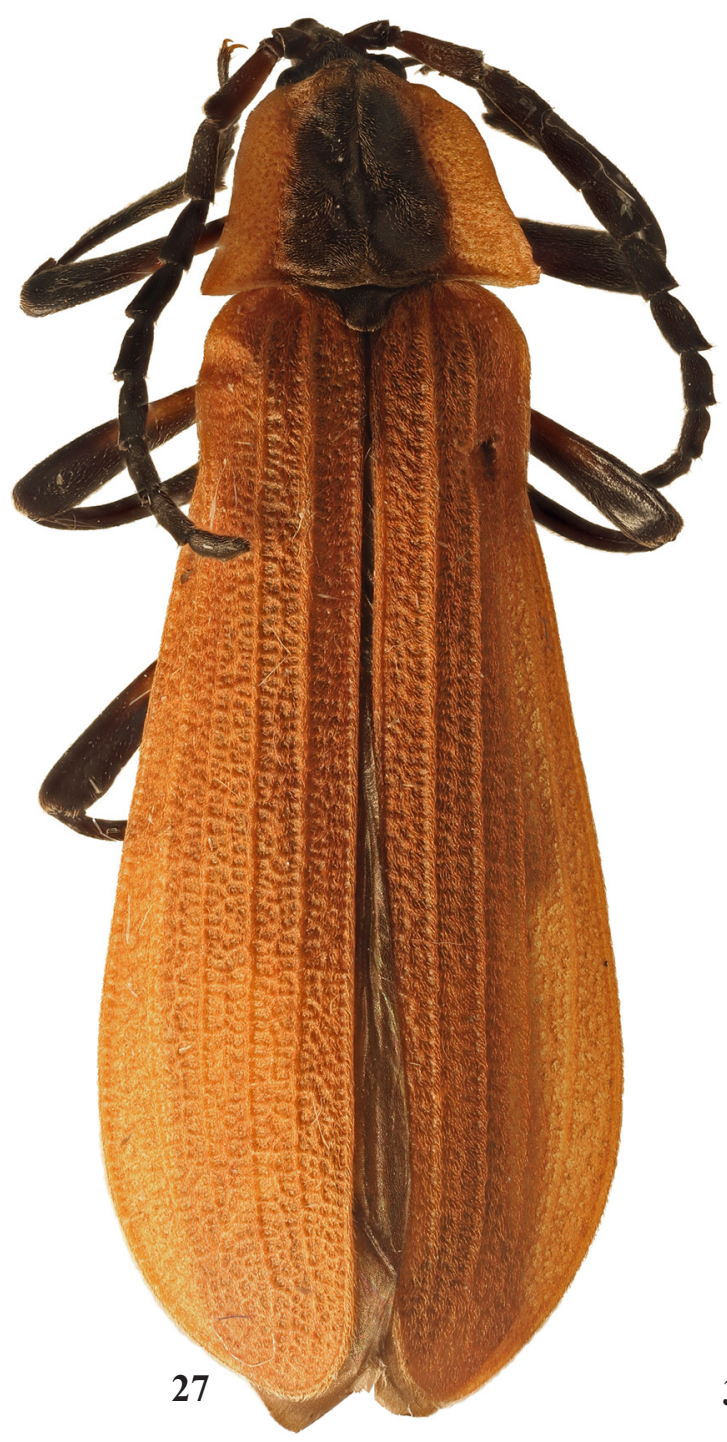

\section{Lycostomus nathani Kazantsev, sp.n.}

Figs 36-39.

MATERIAL. Holotype, $\sigma^{7}$, South India, Annamalai Hills, Cinchora, $3600 \mathrm{ft}$, IV.1957, P.S. Nathan leg. (MUM); paratypes, $4 \mathrm{O}^{7} \mathrm{O}^{7}$ and 22 + 9 , same label (ICM and MUM); $O^{7}$ South India: Tamil Nadu State, Anamalai Hills, Kadamparal, 4200 ft, V.1980, T.R.S. Nathan leg. (ICM); $1 \sigma^{7}$ and 4 우, [South] India, Pulney/Palni Hills, Kodaikanal, 6500 ft, V.1953, P.S. Nathan leg. (ICM and MUM).

DESCRIPTION. Male. Dark brown to black; broad pronotal sides and elytra orange red.

Vertex shining, finely and densely punctate, relatively densely pubescent, with a pair of small round impressions behind antennal prominence. Eyes relatively small, interocular distance ca. 1.5 times greater than eye diameter. Rostrum moderately long, ca. 1.3 times longer than wide proximally, anteriorly concave. Labrum transverse, rounded anteriorly and at sides. Maxillary palps slender, ultimate palpomere elongate, parallel-sided, rounded and glabrous distally. Antennal sockets separated by minute lamina. Antennae robust,

Figs 27-31. General view and details of Lycostomus kwanshanensis sp.n., male, holotype: 27 — general view; 28 - rostrum; 29 ultimate abdominal segments; 30-31 - aedeagus; 27-30 - dorsally; 31 - laterally. Scale: $1.0 \mathrm{~mm}$.

Рис. 27-31. Общий вид и детали строения Lycostomus kwanshanensis sp.n., самец, голотип: 27 - общий вид; 28 - рострум; 29 - вершинные брюшные сегменты; 30-31 - эдеагус; 27-30 - сверху; 31 - сбоку. Масштабная линейка: 1,0 мм. 
dentate, attaining to elytral two fifths; antennomere 3 ca. 6.2 times longer than antennomere 2 and ca. 1.2 times longer than antennomere 4; antennomeres 3-11 with short scarce short erect hairs (Figs 36-37).

Pronotum transverse, ca. 1.3 times wider than long, slightly narrowing anteriorly, bisinuate basally and semi-circularly produced forward in median third anteriorly, with acute posterior and rounded anterior angles; median rib developed in anterior third, with median groove in middle third. Scutellum triangular, rounded at apex (Fig. 36).

Elytra ca. 3.2 times longer than wide at humeri, noticeably widened posteriorly, widest in distal fourth, with four relatively weak and equally developed primary costae, except stouter first costa in proximal half; interstices with irregular reticulation obscured by short dense decumbent pubescence. Femoris and tibiae narrow, femoris straight, tibiae noticeably curved; tarsi relatively wide, tarsomeres 1 and 2 with plantar pad in apical two thirds (Fig. 36).

Spiculum gastrale relatively short and broad, proximally rounded, not widened. Aedeagus symmetric, with relatively short, almost straight at apex median lobe; parameres relatively broad, violin-shaped, fused to median lobe, ca. 0.4 length of median lobe; phallobase elongate, ca. 1.4 times longer than wide and about 0.4 length of median lobe, with triangular distal opening, traceable lateral apodemes and a pair of evident sutures proximally (Figs 38-39).

Female. Similar to male, but antennae somewhat shorter.

Length: $11.6-18.9 \mathrm{~mm}$. Width (humerally): $3.0-5.2 \mathrm{~mm}$.

DIAGNOSIS. Lycostomus nathani sp.n. is also similar in general appearance to L. honestus, distinguishable by the uniformly orange testaceous elytra and noticeably less produced laterally hind pronotal angles, as well as by the structure of the aedeagus, with broader, both in ventral and lateral aspects, and less bent, in lateral aspect, median lobe and violin-shaped fused parameres (Figs 36-39).

ETYMOLOGY. The new species is named after the collector of the type series.

REMARKS. Both 'Annamalai' and 'Anamalai', and 'Pulney' and 'Palni' spelling is used in the manuscript labels under the specimens of the type series.

ACKNOWLEDGEMENTS. It is my pleasant duty to express gratitude to Dr. Mathias Hartmann (Erfurt, Germany), Dr. Dmitri Logunov (Manchester, UK) and the late Dr. Michel

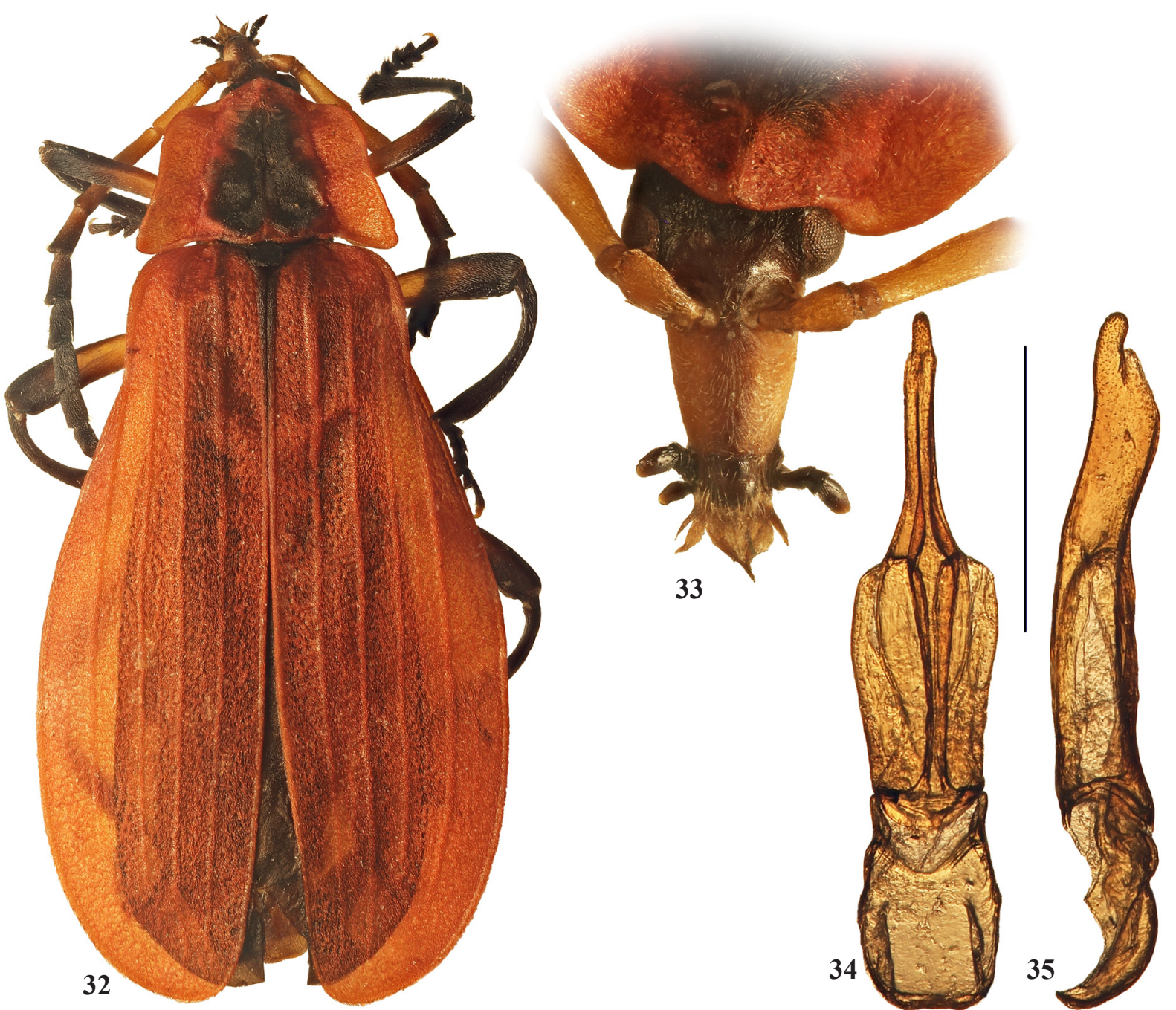

Figs 32-35. General view and details of Lycostomus lushanensis sp.n., male, holotype: 32 - general view; 33 — rostrum; 34-35 aedeagus; $32-34$ - dorsally; 35 - laterally. Scale: $1.0 \mathrm{~mm}$.

Рис. 32-35. Общий вид и детали строения Lycostomus lushanensis sp.n., самец, голотип: 32 - общий вид; 33 — рострум; 34-35 эдеагус; 32-34 - сверху; 35 - сбоку. Масштабная линейка: 1,0 мм. 


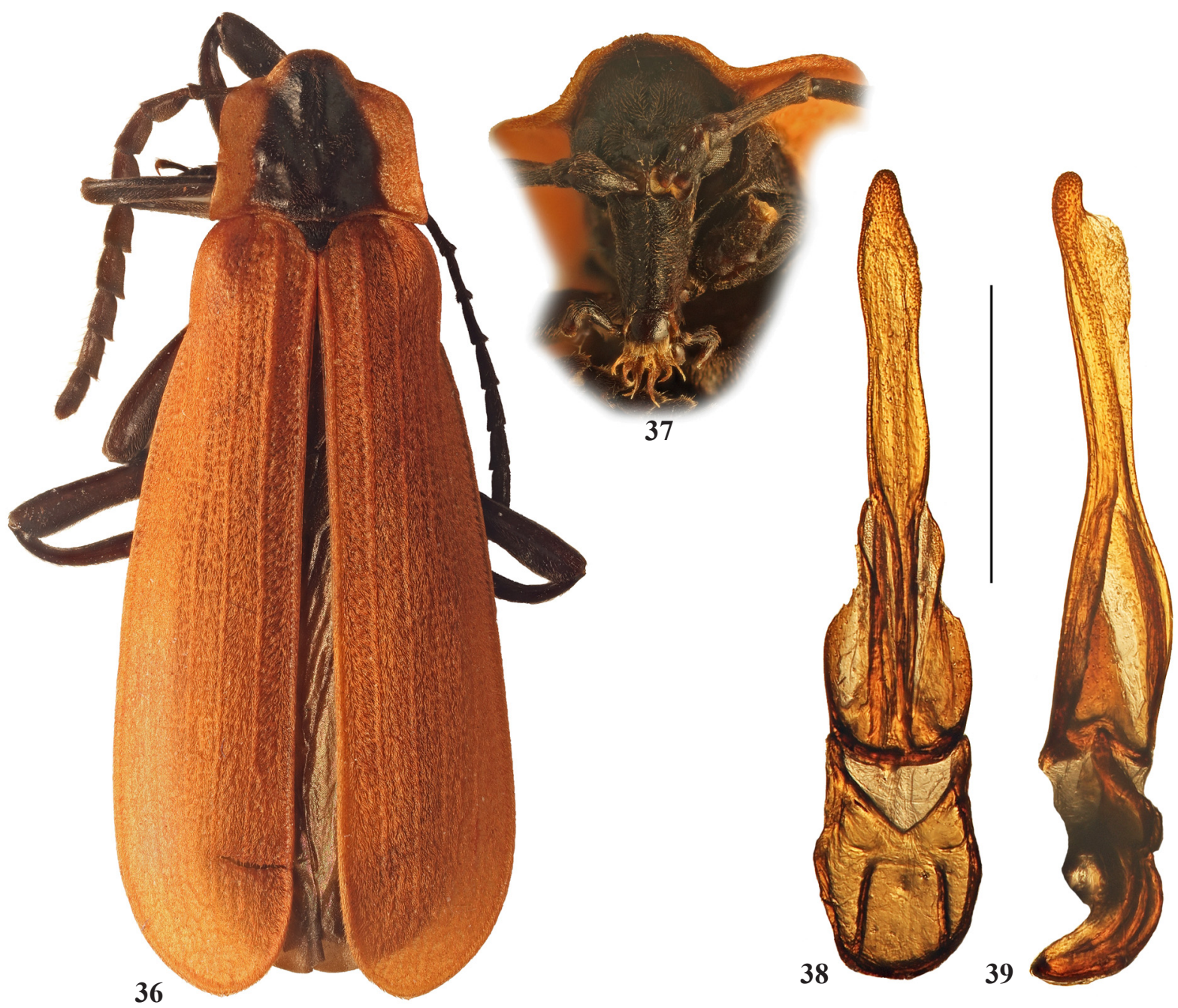

Figs 36-39. General view and details of Lycostomus nathani sp.n., male: 36 - general view; 37 - rostrum; 38-39 - aedeagus; 36, 38-39 - holotype; 37 - paratype; 36-38 - dorsally; 39 - laterally. Scale: $1.0 \mathrm{~mm}$.

Рис. 36-39. Общий вид и детали строения Lycostomus nathani sp.n., самец: 36 - общий вид; 37 - рострум; 38-39 - эдеагус; 36, 38-39 - голотип; 37 - паратип; 36-38 - сверху; 39 - сбоку. Масштабная линейка: 1,0 мм.

Brancucci (Basel, Switzerland) for the opportunity to study the lycid material under their care, as well as to Dr. Carolus Holzschuh (Villach, Austria) and Dr. Igor Melnik (Moscow, Russia) for handing over the net-winged beetles collected during their trips to southern Asia.

\section{References}

Bocáková M., Bocák L. 2007. Lycidae // I. Löbl, A. Smetana (eds.). Catalogue of Palaearctic Coleoptera. Vol.4. Stenstrup: Apollo Books. P.211-224.

Kazantsev S.V. 1991. To the knowledge of oriental Lycidae (Coleoptera). Remarks on Lycidae of Himalaya // Entomologica Basiliensia. Vol.14. P.153-182.
Kazantsev S.V. 1993. Lycides nouveaux ou peu connus de l'Indochine (Coleoptera) // Bulletin du Muséum National d'Histoire naturelle. Paris, 4e ser. Vol.15. Section A (1-4). P.49-68.

Kazantsev S.V. 2012. An annotated checklist of Cantharoidea (Coleoptera) of Russia and adjacent territories // Russian Entomological Journal. Vol.20 (for 2011). No.4. P.387-410.

Kleine R. 1933. Pars 123: Lycidae. Coleopterorum Catalogus auspiciis et auxilio W. Junk editus a Schenkling. Berlin: W. Junk. $145 \mathrm{p}$.

Kleine R. 1937. Les Lycides du Congo Belge // Annales du Musée Royal du Congo Belge. Ser.3. Vol.2. No.6. P.61-120.

Motschulsky V. 1861. Essai d'un catalogue des insectes de l'île Ceylan. Lief. 1 // Bulletin de la Société Impériale des Naturalistes de Moscou. Vol.34. No.2. P.95-155.

Waterhouse C.O. 1879. Illustrations of Typical Specimens in the Collection of the British Museum. Part 1 - Lycidae. London: Taylor and Francis. P.93. 